\title{
RELIGIOUS EDUCATION AND COMMUNITY DEVELOPMENT: A STUDY ON THE PONDOK AND ITS EFFORTS TO REALIZE THE PHILOSOPHY OF ISLAMIC EDUCATION
}

\author{
Abdul Razak @ Abdulroya Panaemalae \\ Lecturer, Asean Studies Program, School Of Liberal Arts, \\ Asean Studies Program, School Of Liberal Arts \& Director, Islamic Study And \\ Muslim Community Development For Peaceful Social Integration Project, \\ Walailak University
}

\begin{abstract}
The work is trying to show how relevant the pondok education is with the philosophy of Islamic education itself. The research recognize that there are still many weaknesses that need to be changed in the education system of the pondok, so that they continue to stand and live to provide the religious spirit to every Muslim as has been proved before. Yet these benefits outweigh the weaknesses. It should not be repealed. It is important to find new formulas to empower this institution in line with the changes in time. It is something which has been proven to be good and useful to mankind, so there is no need to bother to change it. Although there are wooden frames and a roof that need to be replaced, and water wells that should be constructed to ensure the water flows, but again there is no need to destroy what has been strongly built. The good values of each item are fixed. It is also the role of pondok education in religious education that has played an effective role in order to form a noble personality and civilized humans in accordance with the Islamic principles.
\end{abstract}

Keywords: Religious, Education, Pondok, Philosophy, Islamic and Community.

\section{INTRODUCTION}

This paper tries to explain and prove how the pondok (Islamic boarding school) education system is closely related to the philosophy of Islamic education. This paper is based on the author's observations on the educational situation in South Thailand. The author's wish to provide the answer and correct the perception of some parties including the Thai authorities (read: the armed forces) on the so-called pondok education system as a 'camp' for militants and violence will be proved in this paper. To date, the author believes that there 
are people who still have a negative perception on the system and educational institutions of pondok or religion. The average view of the system and this institution is no longer relevant to the globalized modern world. This paper will attempt to to provide clarification in this regard. However it is not going to discuss the concept and development of the pondok in southern Thailand in more detail. On the other hand, it will focus on the discussion of the concepts and philosophy of Islamic education and its connection to pondok education.

The pondok education covered in this article does not focus only on the traditional pondok education (including the pesantren, a term commonly used in Bahasa Indonesia) but it includes a wider purpose, namely modern pondok education or more accurately referred to as the madrasah. Even in a specific context as well as the form of religious education in other forms such as religious education in surau (small mosque), mosques, kindergartens, colleges and universities. Nevertheless, this discussion is more about the traditional education called 'pondok < and religious education of modern trend called madrasah'. Although the two educational institutions, the pondok and the madrasah, have differences in terms of terminology, concepts, methodologies and structure, the writer put them under the same category, based on the topic in the context of this discussion, into a single name, i.e. the 'pondok education'.

In fact, the name is not uncommon in the context of modern society. This is because when referring to the religious educational system, it brings the connotation of understanding to the pondok and madrasah. It is the habit that when people mention 'pondok education or 'pondok school', it directly gives connotation to Islamic religious educational institutions. More importantly, the author is trying to show how relevant the pondok education is with the philosophy of Islamic education itself.

\section{EDUCATION AS A DEVELOPMENT MECHANISM}

Education is the mechanism of human development towards the most practical perfection of life. Human achievement in science and technology now is very commendable. Such achievements have never been accomplished in the history of human civilization. Humans now live in a world full of various manmade technologies. They live rich and more comfortable compared to the primitive society. The achievement of this development represents that humans are at the top of the civilization. As Dr. Hasan Langgulung (1998) was quoted as saying: "Education is an important mechanism in building human civilization." Achievements in development will not be accomplished by humans if without going through proper and systematic education system. Only through education can human reach development and build new civilizations. This prem- 
ise is agreed upon by the entire human community in the world. Anyone of different religious and cultural background would all agree in this regard.

In other words, no one rejects the truth and importance of education in the lives of modern times. In the process of construction of countries around the world today, the field of education is the most important agenda preferred by the authorities. Generally, people have similar oponion, that is, if you want create a state, make sure every citizen receives adequate education. This is evidenced by the emergence of giant countries in the world today such as the United States, Britain, France, Germany, Japan and Korea which are very influential in the world due to their achievement in science and technology. This condition occurs in line with the educational process carried out in those countries. Undoubtedly, if you want to develop, you must be educated.

Education is the most important mechanism in an effort to develop a nation. The question is "what kind of education is meant here?" And if it is true that education leads to development, why does the advanced world as we see today cope with various life crises? If we now are highly developed, why do more and more people have moral degradation? We see more and more cases of corruption, breach of trust, robbery, murder, rape and so forth. Such cases often happen among the elites who are highly educated such as politicians, government officials, medical doctors, teachers and others. In the history of modern human civilization, there were two great world wars that claimed millions of lives. Many lives were lost as a result of the two world wars. This does not include a series of small wars erupting in some countries in the world. Even there is no indication that this series of wars will end soon. On the other hand, there are signs that new series of wars will probably be greater than the past. So when a situation like this occurs, it is appropriate that we ask, "Are really developed?" Or are we actually in the process going backward? Why is it that the more the sophistication of modern equipment and the achievement of science and technology we had, the more increasingly we are in a dilemma? Where is wrong?

A famous Malaysian culture activist, Datuk Dr. Hassan Ahmad discussed the matter and said:

"Within a long period of time until the 21st century, mankind has not advanced, but is still primitive. Advanced on the outside, but not in the inside. His knowledge advances but his manners and his heart are not. His reasoning is growing but his morality is not. In many respects, he is not different from animals that live in the wild, without morals, without manners, without civilization. Humans are not developing in 
accordance with the will of his Creator. " (Dewan Budaya, Disember 2002).

Based on the quotation from Datuk Dr. Ahmad Hassan we can say that humans are caught in the myth of progress and development of their creations because the aspects of progress focusing on the process of human development is not balanced, i.e. putting more emphasis on the external (physical) aspects and ignoring the internal or spiritual. Such development and progress as argued by Prof. Dr. Wan Mohd Nor Wan Daud (2001) as a zerosum development which is a development based on physical and not spiritual progress, which eventually fails to provide a balance to human life in the real sense.

In short, we do not reject the premise that says that education is a mechanism of development. However, at the same time we should also be aware that education can also act as a 'two-bladed' sword that may bring trouble to us and society if it is not based on proper educational philosophy that brings wellbeing. Therefore, we might say that education is the root of all problems. As Dr. Prawet Watsri, a Thai scholar, in one of his lectures at the Thai Christian Center in December 2005, proposed to turn back the currently practiced education system. He is confident that if the education system is correct, it could solve all the problems.

\section{HUMAN NATURE AND DEVELOPMENT CONCEPT}

Man in Islamic religious tradition is also referred to as al-Insan that is the most special God's creature. It is the most perfect creature of God as revealed in surah al-Tin verse 4 , which means "we created human beings in the best possible form" because man is formed from three key components, namely the body, spirit and intellect which distinguishes him from animals which only possess the body but has no common sense. So is the case with the angels who only posses the spirit and common sense but without flesh. However, man has all the elements which enable them to develop in the form of the best creature, particularly the sense that enables him to think towards building civilization in the world. By virtue of his own rational intellect, he is called the 'rational animal' or in Arabic 'al-hayawan natiq «. Man is created in such a way to serve as a khalifatullah (vicegerent) on this earth. He is entrusted with the role and duties as God's creature responsible for completion of life on this earth. These heavy duties are unable to be carried out by other creatures of God such as the hill, mountain, jungle, sea, ocean except humans. In realization of this effort, man needs knowledge to 
illuminate the darkness and drive him towards the right path and not the wrong way. In other words, he needs true knowledge that enables him to know himself and who created him.

Man, in fact, does not have any privileges without assistance and help from his creator. Syed Muhammad Naquib Al-Attas described man as “... an island set in a fathomless sea enveloped by darkness, and the loneliness his self knows is so utterly absolute because even he knows not his self completely." (1993: 81). Thus, without the guidance of God, man will definitely get lost and eventually fall into sin. Moreover, human nature itself is forgetful (nisya') therefore he is encouraged to be guided with revelation in order to get lost. Without guidance, man is just like animals as God said in the Quran: "Those are like livestock; rather, they are more astray. It is they who are the heedless." (Surah al-A'raf: 179).

Therefore, in the principle of the philosophy of development, according to Islam, should not ignore human development. Human development is one of the key elements in the development concept of Islam. Development system in Islam is not only the emphasis on economic growth in the form of profits and financial returns as shown by the secular West. However, excellent personality should also be prioritized in addition to other aspects. This is because the concept of Islamic Development includes aspects of moral, spiritual and material. Development becomes a value-oriented activity and has a goal of the completion of human well-being in all aspects. Aspects of moral, material, economic, social, physical, and spiritual cannot be separated from each other. The goal is not only the welfare of the world, but also toward the prosperity in the hereafter. Such dimensions are missing in the current development concept. As a result of the concept of development emphasizes the external aspects have resulted in humans' failure to reach real happiness. Instead they are caught up in the drama of the tragic life and hypocrisy. Although the world enjoys progress in science and technology, there is no doubt that the progress of human creation is now accompanied with deterioration in other areas. In fact, in the stunning globalization of prosperity also comes with the globalization of poverty which is so pathetic. As a result, this achievement has failed to liberate man from the backwardness and povert $y$ and achieve social justice as expected. As Syed Muhammad Naquib Al-Attas said, even though they managed to take control of the nature; they have transformed the face of the Earth; they have changed the river flow, tamed hydraulic energy; they have penetrated space and climbed the mountains that have never been touched by others; but they have not been able to take control of themselves, to know themselves, to bring peace to themselves (2001: 44). 


\section{THE CONCEPT OF TRUE KNOWLEDGE AND CONFUSION WITH- IN THE MEANING OF KNOWLEDGE}

According to Syed Muhammad Naquib Al-Attas (1993) the endless dilemma of life, especiallyamong the Muslims, is confusion of the conceptofknowledge. Due to the mistake in giving the interpretation of the concept of knowledge, the core of some various problems and disasters of humanity on the environment is inevitable. The cause of this confusion is due to the efforts of people trying to separate the religious teachings from life, or even undermine the system of religious life. Finally, symptoms of confusion of knowledge spread among them. As a result of the confusion of knowledge, there are many false intellectuals, false leaders, and false scholars that have dominated the walks of life. They have good positions, and placed in a comfortable and dignified place based on the knowledge they possess as well as their contributions to the country's development and progress of the nation. However, they are no more than confused people who were born under the educational system based on confusion of knowledge.

This situation is a phenomenon that is harmful and most critical faced by all human beings nowadays. Therefore to avoid such phenomenon from continuing to dominate our minds, an effort and action to return man to the original concept of knowledge should be taken immediately so that the man will not be caught in a deadly trap.In fact, the problem of the epistemology of knowledge was explored by SyedMuhammad Naquib AlAttas in describing the concept of true knowledge. He was among the figures of contemporary Islamic scholars who continued to explain the concept of knowledge that is true according to the Islamic code. A lot of works has been produced by him that lead to discussion about the meaning of knowledge and philosophy of education from an Islamic perspective. To prove how much he is committed to knowledge and educational philosophy, we can read his book called "the philosophy and practice of Islamic education of Syed Muhammad Naquib Al-Attas: an Original Description of Concept of Islamization" by Wan Mohd Nor Wan Daud (University of Malaya: 2005).

In one of Wan Mohd Nor Wan Daud's works, Guidance For Muslims (2001), Syed Muhammad Naquib Al-Attas described the meaning of true knowledge in detail. The author is pleased to quote him as saying:

"Knowledge is a process or motion-force of acquiring knowledge and refers to a characteristic in a living creature (man), allowing himself to know what is known. Knowledge is also the recognition of what is known as the way it is. The recognition that believes in the truth, 
and refers to wisdom. It is something reassuring and provides real understanding. Recognizing and knowing something is to recognize and know e reasons of existence and condition of something known and unknown. Knowledge is an intuitive force to acquire or produce something by common sense that sees the fact as the way it is. Knowledge is also acquired by our heart about something, that reflects the fact clearly and accurately, be it something tangible or in the invisible world. Knowledge is personal or heart setting about the truth of something we have a doubt about it. The knowledge is a strong and unchanged conviction in the heart. Knowledge is a force toward explanation, decision and determination. Knowledge should revisit to the truth. Knowledge is the pledge of about the truth. Knowledge is something like the intention of the nature of something as the way it is. Knowledge provides personal tranquility. Knowledge is a reminder, an overview of common sense, contemplation, inner views. Knowledge is a property that wipes out ignorance, suspicion and prejudice. Knowledge is a reality in itself. Knowledge is the light placed by Allah Almighty in the heart. Knowledge is the description of the heart, understanding of the mind and the force that forms all the things mentioned. Knowledge is internal matters, not external things. Knowledge is science or fixed identification that denies the possibility of science and recognition otherwise. Knowledge is the secret that is inserted into oneself and settles there, and knowledge is the passion and the will of oneself. (m.s. 51-52).

The description by Syed Muhammad Naquib Al-Attas is very precise and clear. It can be summarized that the concept of knowledge is divided into two major categories, that is, illuminativeknowledgeand scientificknowledge. Illuminative knowledge (ma'rifah) is self-identification, because 'anyone who knows himself will know God.' In other words, the knowing oneself leads to knowing God. This knowledge is the primary knowledge and is the highest knowledge that is required on every Muslim. Without this knowledge, this Muslim person will be imperfect. Thus, this type of knowledge becomes the obligation on each person to seek or claim. As the Messenger of Allah said, «seeking knowledge is obligatory for every Muslim, male and female". Thus, it is not surprising why Syed Muhammad Naquib Al-Attas asserted "... why knowledge (al-' ilm: ma'rifah: 'ilm) occupies the most important position in Islam» (1993: 78).

As for is the scientific knowledge that is given by God to man and can be accessed through rational research efforts. Scientific knowledge could help us to achieve perfection, as long as it is always controlled, evaluated and directed by illuminative knowledge. In other words, if scientific knowledge is 
not guided correctly by illuminative knowledge, it could lead to damage, destruction and fraud to thesystem of humanlife. Thisisthepositionof knowledge which is not required on all individuals but only on certain people who are qualified and capable of mental and physical strength, especially brain intelligence.

\section{MODERN EDUCATION SYSTEM AND DIVERGENCE OF CONCEPT OF KNOWLEDGE CULTURE}

Before further discussion leads to the definition and philosophy of education in Islam, the author felt that the philosophy of modern education sponsored by the Western secular beliefs should also be discussed. Thus, we should review the concept of modern secular education and see its implications on human development. This isintended for comparison between the philosophy of Islamic education and that of the secular West. This is important because on average the world's education now leads to and adopts the same education system, i.e. the system that is no longer related to religion. Education now emphasizes more on scientific knowledge rather than illuminative knowledge. Secularism is the original philosophy that tends to separate between religion and all worldly matters. As a result, knowledge has become merchandise that has economic value. In seeking knowledge, students have to pay to gain a certificate. When students have to pay expensive to get education, they plan on getting back what has been spent in the academic world. According to Wan Mohd Nor Wan Daud (2001), the result of education being stuck with market ideology and industries then "knowledge has lost its values and spirit of humanity, and has be restricted economic and political commodity.'In other words, we now understand that knowledge in modern times is no more than individual socio-economic mobilization tool to achieve the comfort and luxury of life in the world. As a result, Ronald Dore referred to it as the "Diploma Disease", which is a phenomenon of race especially among students to get a certificate not because of high educational values but merely because of the economic values and social dignity which may be obtained through it.

This disease has changed the position of knowledge culture into exam culture. The value of knowledge is nolonger needed but passing the examination with high grades is more important. The students are oriented on passing the test sometimes through the wrong way. This is a crisis not only faced by modern countries but Muslim countries were also already stuck together in it. Syed Muhammad Naquib Al-Attas said that "The secular scholar and intellectuals among the Muslims derive their inspiration mainly from the West." (1993: 124). Muslim students studying religion are said to have the same dilemma. They are not studying religious knowledge to find the 
truth and pleasure of God but they consider the learning process as a "stepping stone" to rank and position in the field of career that eventually lead to success in life. According to Rosnani Hashim (1996), “...students were learning religion only for examination purpose rather than for moral development and practice."

Obviously, current educational system has failed to produce a truly educated person who really knows himself. The general goal of education is to produce good human beings that will be able to produce an atmosphere of harmony. However, because the education system has now been conquered by ideological market and industry, it has resulted in worrying occurrences. For example, a report in the newspaper Matichon on 9 January 2006 uncovered issues about fraudulent activities among students. They asked for money for living expenses as well as tuition fees from their parents by giving false receipts to claim the fees in excess of the limits set by the University. Such behavior at least provided us with a picture of morality among students. It seems that the system is teaching to cheat or to be 'corrupt' even when they are still in school. Imagine what would happen if one day they become professionals working in the community.

Such concerns have been voiced by J. Krishnamurti in his book "Education and the Significance of Life:

If we are being educated merely to achieve distinction, to get a better job, to be more efficient, to have wider domination over others, then our lives will be shallow and empty. If we are being educated only to be scientists, to be scholars wedded to books, or specialists addicted to knowledge, then we shall be contributing to the destruction and misery of the worl (1997: 11).

This symptom should be immediately addressed by all parties before it spreads wider, and to ensure that the value of educational knowledge can be placed back at the right position according to the concept of knowledge and education.

\section{MEANING AND PURPOSE OF EDUCATION IN ISLAM}

In view of the modern education system failure and the emergence of social problems among mankind, some Muslim scholars agreed to hold a special international conference to discuss education and reassess the concepts and philosophy of education. Finally, the International Conference on Islamic education was successfully held in Mecca in 1977, which was attended by 313 Islamic scholars from 40 countries. As a result, Muslim scholars agreed to formulate the definition and goals of 
education in Islam as to produce "a good and righteous human", who worships only Allah, establishing Sharia-based civilization, and living with guidance of Sharia. Muslim scholars' effort here is not aimed at changing the original philosophy of Islamic education in another form to meet the suitability of the ummah today. It is not necessary because the religion of Islam has provided complete guidelines about the philosophy of education. It is simply intended to renew and commemorate the return of the original philosophy of education according to Islam and thus as a noble effort to show commitment toward the establishment of the educational system based on the concept of tauhid. The outcomes of the decisions made do not conflict with what is contained in the Quran and Sunnah. All of which are directed to the formation of the noble human character that obeys God.

The values of virtues and standards set out in the religious teachings do not need to be changed according to the changing times and circumstances. Thus, nobody should change the values as changing them would only cause confusion. So is the case with Islamic religious values that have been enshrined in the Qur'an. Our task is simply to practice what has been set out by the Creator. For example, usury is forbidden so it is always forbidden. There are no exceptions in the case of the law. Religious educational institutions either in the form of mosques, surau, pesantren, schools, religious schools, colleges, universities or in any other form all have a common goal, namely to educate human beings to become good and righteous. A good man is synonymous to a civilized human. Any education system that set religious education aside will certainly fail to produce a civilized human as religion (al-din) cannot not separated from the aspects of spiritual or faith. Faith is the basics of the education in Islam. When humans have faith, they will become a good and civilized human. A good man is someone who has adab. This is the essence of real education in Islam.

The question of a civilized human is what is expected by everyone including parents and the rulers in all countries. This is because a good man naturally should be a good servant to God, good father to his children, a good husband to his wife, a good child to his parents, a good neighbor and a good citizen to his country (Wan Mohd Nor Wan Daud, 2005: 129). Strictly speaking, a good human is the core of citizenship. The concept of good man is in contrast to the concept of a good citizen. Good citizens, which become an important agenda in modern countries do not necessarily consist of good people. Good citizens probably just are made up of human with competence, high skills in the field of professional expertise in specific areas and with high education. However, a good man has responsibility to his God, maintaining justice in the com- 
munity; man in his behavior always nurtures himself toward perfection as a good human (Syed Muhammad Naquib Al-Attas, 2001: 43).

Theeducational purpose in Islam is not only to produce people who have a degree, it also has the purpose of further than that. This is because knowledge from the perspective of Islam is “... infinite since it originates from and ends in God..." (Wan Mohd Nor Wan Daud, 1989: 113). So, the purpose of Islamic education is seeking values of spirituality, religion and tauhid as the main agenda in the framework of education. To see more clearly about the purpose of this education, the author is pleased to quote S. H. Nasr in his book Traditional Islam in the Modern World, as saying:

"Not only to train the mind, but also to train whole potential as human beings. That's why, it is not just teaching or propagation of knowledge ( $\mathrm{ta}$ 'lim), but also to train the whole personality of the students (tarbiyah). Teachers are not only an instructor (mu'allim) who spread knowledge, but also an educator (murabbi), who trains the soul and personality. It is true, in particular, the term mu'allim itself can reach a meaning of murabbi; but it must be given the meaning of moral character in the modern world which has been transformed into something that is separated in total of the teaching and dissemination of knowledge, particularly at the level of higher education."

For this purpose, religious education institutions, as well as pondok, should practice the above ideology to achieve the original purpose of Islamic education. Muslims have never been questioned about the issue of the form of learning institutions. Universities and madrasah or pondok all have a role and a common goal, which is to educate people to be good and righteous. What is importantan is that the institution is responsible for spreading the spirit of religion into students' lives as well as Muslims.

\section{PONDOK: THE ROLE AND CONTRIBUTION AS WELL AS ITS RELATION TO THE PHILOSOPHY OF ISLAMIC EDUCATION}

Pondok has undergone transformation as times change and as a result of the occurrence of a change in the leadership of the Thai Government from time to time. The 'pondok < turned into speople's religious school' and then turned into 'madrasah < in the end. Despite the changing in pondok education from time to time, the philosophy of Islamic education does not change. The only difference is that in the form of traditional pondok education the system of 'book study' to deliver and pass down knowledge to students is commonly used. While in modern education, the school system has classes 
and examination and issuance of a certificate as a proof that the student has passed the tests of the examination. However, the importance of the role and contribution of pondok education does not move away from basic Islamic education. In other words, despite the different education approach, the goal remains the same which is to produce a good human.

The contribution of eduction in an effort to expand the Sharia and empower Islamic religious culture is huge and indisputable especially to Muslims in the region and the Islamic world itself. This can be proved with the advent of some great local scholars such as Sheikh Daud bin Abdullah Al-Fatani, Sheikh Ahmad bin Muhammad Zain Al-Fatani and Zainal Abidin bin Muhammad Al-Fatani (just to mention a few names only), who not only have contributed to the Muslims in the Malay world only but have also contributed their knowledge to Muslims outside the Malay world. Their works until now are still under review, examined and made a mandatory religious learning material in some pondok or pesantren. They are scholars who have great contribution to the Malay civilization particularly, and Islamic civilization generally. The author did not mean to speak more about heroes and the personality of local scholars, but just wanted to show how important the contribution of pondok education to the Muslim Malay in the region. The report from the selection Committee of the Malaysian Financial Assistance to non- Government Islamic religious schools in 1957 said that "The Pondok played a great role in building up a peaceful and well organized society among the people of this country and in combating illteracy and producing Alim Ulama and wise men."

To view the existence of pondok education in the Malay civilization, I would like to quote a researcher who did research on the pondok, Mr. Zaidi Hassan (2001), who explained that traditional Islamic education including pondok education has demonstrated its success which stands out in our region. It is the backbone for the Malay civilization and Islam. This kind of education has led to the Malays to appreciate Islam not only in terms of rituals, but also have been able to distinguish between clean and dirty, such as feeling queasy when seeing a pig, take care of the dirty clothing and making sure food is clean and hygienic as such habit is required before prayer. Important custom in life of many Malays have based on Islam. Beginning with the azan whispered when celebrating a child birth. When this baby has become a kid, he is circumcised and taught to pray and read the Quran. When he reaches adulthood, he is married in a wedding ceremoby. When he is wrapped in white cloth, prayed and buried, followed by the recitation of talqin, then the tahlil is held for him. The pondok has strengthened the existence of all this practice in the community from generation to generation. 
Thus, we could say that, in the context of Southern Thailand, pondok education is a Malay version of Islamic education. Pondok is born based on the religious mentality of the Malays. It is born from the intellectual awareness of the local Malay community who feel responsible to learn and delve in religious sciences (illuminative Knowledge). It is the only educational institution that is the foundation and has been influential to the religious life in the context of the Malay community since the beginning of Islam in the Malay Archipelago until now. It is suitable to the taste and the climate of Muslims in the region.

\section{PONDOK AS AN OPEN UNIVERSITY}

Pondok education has become the religious strength among the Muslim-Malay community. It is a pride to the Malay itself. For example, traditional pondok education is very unique. Its uniqueness in contributing religious education to the natives is irreplaceable. There is no educational institution similar to pondok that is really open and free to enthusiasts of knowledge. "Education in pondok was free and open to Muslims of all ages"(Rosnani Hashim, 1996: 21). Students do not need to pay a fee; they just need to pay a little for electricity and water as well as the requirements that do not burden the students and their parents. "The pupils did not pay fees, but donated money to buy kerosene for the oil lamps that were used if classes were held at night. More often the pupils assisted their teachers with such chores as carrying water from the well, carrying firewood, or growing and harvesting rice in the fields." (Rosnani Hashim, 1996: 20). In addition, they are free in the study. It depends on the comfort of the students because their learning is not assessed in the examination but is for the good of themselves and the community. "There were no examinations, and promotion to higher level was determined by students' capabilities. Thus, the length of study depended on the students themselves" (Rosnani Hashim, 1996:21). While the teacher is called tokguru or toklebai and do not expect sympathy from others because it is based on a sense of obligation to provide knowledge to those who want to learn. "The teachers were not paid a salary. They led simple lives, made great sacrifices in time and energy, and worked from a sense of duty " (Rosnani Hashim, 1996: 21). It has become a mandate to those who know to tell to those who do not know. They expect the divine pleasure alone. In fact, they expect rewards in the hereafter.

Another uniqueness and pride of pondok education that is also worth mentioning here is the application of independence among the students. All students are required to stand on their feet during their study at the pondok. Pondok does not provide any facilities for food, clothing and 
even shelter, so students have to build their own. The education world in the pondok is open wide for them to learn during the study period and during their stay at the pondok. The minutes and life during their stay in the world of pondok are the most valuable chapters of education. Norms of life like this actually is the initial setup to the students before they enter the world of adulthood which is full of twists. It is a training that enables them to know themselves in all fields of life. They grow up with maturity as a human being. Thus, the phenomenon of unemployment hardly ever occurred among students graduating from religious educational institutions, and this includes the pondok education itself.

\section{CONCLUDING REMARKS}

It is recognized that there are still many weaknesses that need to be changed in the education system of the pondok, so that they continue to stand and live to provide the religious spirit to every Muslim as has been proved before. Yet these benefits outweigh the weaknesses. It should not be repealed. We just have to find new formulas to empower this institution in line with the changes in time. It is something which has been proven to be good and useful to mankind, so there is no need to bother to change it. Although there are wooden frames and a roof that need to be replaced, and water wells that should be constructed to ensure the water flows, but again there is no need to destroy what has been strongly built (HassanZaidi, 2001: 16).

The good values of each item are fixed. The value of a piece of gold, even a thousand years have passed by, will remain the same. In fact, as it gets old, gets better in terms of its value. Similarly, it is also the role of pondok education in religious education. It has played an effective role in order to form a noble personality and civilized humans in accordance with the Islamic principles.

\section{REFERENCES}

Hasan Langgulung, "Islamic Education and Human Resource Development in Moslem Countries" in KESTURI Jan-Jun 1998 published by ASASI (Akademi Sains Islam Malaysia).

Hasan Madmarn, 1999. The Pondok \& Madrasah in Patani', Bangi : UKM Press.

Hassan Ahmad, Datuk Dr., “Tanda Manusia Maju di Luar” dalam Dewan Budaya, December 2002.

J.Krishnamurti, 1997. Education and The Significance of Life, Madras: Krishnamurti Foundation India. 
Matichon, 18 Doisember 2005.

Matichon, 4, 5, 6 dan 9 Januari 2006.

Misran Rokimin at. all (Eds.), 2002. Falsafah dan Peradaban Pembangunan, Bangi: UKM Press.

Mohd. Affandi Hassan, 1992. Pendidikan Estetika daripada Pendekatan Tauhid, Kuala Lumpur: Dewan Bahasa dan Pustaka.

Muhammad Syukri Salleh (Eds.), 1990. Konsep dan Pelaksanaan Pembangunan Berteraskan Islam, Pulau Pinang: USM Press.

Rosnani Hashim, 1996. Educational Dualisme In Malaysia: Implications for Theory and Practice, Kuala Lumpur: Oxford University Press.

Syed Muhammad Naquib Al-Attas, 1993. Islam and Secularism, , Kuala Lumpur: ISTAC.

1999. The Concept of Education In Islam. Kuala Lumpur: ISTAC. 2001. Risalah Untuk Kaum Muslimin, Kuala Lumpur: ISTAC.

Wan Mohd Nor Wan Daud, 1989. The Concept of Knowledge in Islam and Its Implications for Education in A Developing Country, London and New York: MANSELL. 1995. Penjelasan Budaya Ilmu, Kuala Lumpur: Dewan Bahasa dan Pustaka.

1996. "Insan Baik Teras Kewarganegaraan" dalam PEMIKIR, January-March.

2001. Pembangunan di Malaysia: Ke Arah Satu Kefahaman Baru Yang Lebih Sempurna, Kuala Lumpur: ISTAC. 2005. Falsafah dan Amalan Pendidikan Islam Syed Muhammad Naquib Al-Attas: Satu Huraian Konsep Asli Islamisasi, Kuala Lumpur: ISTAC.

Zaidi Hassan, "Institusi Pondok: Keberadaannya dalam Peradaban Melayu"kertas kerja yang dibentangkan dalam Kolokium Peradaban Melayu Kawasan Timur Laut, pada 18-20 September 2001 di Kota Bharu Kelantan, Malaysia anjuran Dewan Bahasa dan Pustaka Wilayah Timur. 
